\title{
Overview of Textile and Leather Industries Waste Treatment Processes
}

\author{
Bhanu Pratap Singh* and Pradeep Srivastava
}

\author{
School of Biochemical Engineering, IIT-BHU, Varanasi, U.P., India
}

*Corresponding author

\begin{abstract}
A B S T R A C T
\section{Keywords}

Fused waste administration, Textile, Tanneries, Antagonistic impact, BOD, COD, TDS,

Deflocculation, Salinization, Alkalization, Waste control

\section{Article Info}

Accepted:

12 November 2020

Available Online:

10 December 2020

Waste control has gone through alterations in most recent numerous years, and as of now reusing and recuperation are an extra imperative consideration the waste from industries is a significant thought, not just due to the amount created anyway likewise because of its capacity detrimental effect on ecological and human wellbeing. Fused waste administration might be a structure for planning and forcing new waste-administration frameworks and for examining and upgrading present frameworks. Inside this structure, every specialized and nontechnical added substances of the administration gadget should be investigated together. Here we are worried about textile and tanneries squander sway and the amount and nature of the poisons released. Talking quickly a gigantic measure of profluent produced from tanning and material businesses is being released ashore or into water sources. These effluents are described by physical, synthetic or organic attributes, example, BOD COD. These effluents additionally contains certain optional plant supplements, example, nitrogen, phosphorous, sulfur, magnesium, calcium and so forth just as micronutrients and hefty metals. Expansion of tannery waste and material waste causes deflocculation of soil particles, increment in nitrogen, phosphorous level accordingly causing antagonistic impact on the yields bushes trees just as water bodies. It has been noted salinization and alkalization of groundwater have been taken note. Actual attributes of these don't allow its removal straightforwardly into inland water or ashore for satisfaction of horticultural practices. Henceforth, Today a current day coordinated waste control that imbues maintainability into all added substances while considering help convey and call for is required.
\end{abstract}

\section{Introduction}

The ascent of worldwide principles has arisen as a dubious new subject matter within the literature on alternate and consequently the surroundings in recent years. This paper makes an empirical contribution to the rising literature on global standards and export competitiveness by analyzing how an exertions-in depth developing-us of an enterprise (Indian leather items and textile and apparel) complied with an advancedglobal environmental fashionable that affected exchange and marketplace access. In response to many interrelated components, which incorporates better expenses of garbage removal, more prominent severe authoritative prerequisites, and developing natural center, enterprises are continually actualizing more noteworthy supportable procedures to 
decrease subjective and quantitative business contamination masses and to reuse water and waste. Creation and handling businesses burnthrough great estimated amounts of energy and water, and delivers enormous limits of wastewater.

Indian assembling industry has seen fast improvement after the usage of the new business strategy of 1991. The change assignments of the approach have prompted enhancements in TFP for a portion of the enterprises. During the primer yrs. of industrialization, specialists has offered priority to little scope ventures which make a commitment eminently to net home product, business innovation and fare. Notwithstanding, numerous investigations also featured the awful issue of little scope businesses like wasteful utilization of help, negative natural consistence and subboundless working circumstances which has direct concerning efficiency execution of an organization. While for a larger than average organization, it is less convoluted to misused economies of scale to improve its efficiency. It have discovered variant in TE across states which is presumably credited to qualification in infrastructural improvement like get passage to power, delivery and verbal trade offices.

Business use of those assets is additionally answerable for the disposal of an enormous extent of effluents, ensuing in issues about the treatment and disposal of effluents and effect associated with discharges to the surroundings and water first-class.

The primary parts to be contemplated in wastewater treatment are covered inside the accompanying classes:

Adjourned Solids,

Organic effluence (Biodegradable),

Infectious Microbes or agents (Pathogens), Food Source for Microbes (Nutrients),
Priority ("Toxic" as defined in Clean Water Act, USA) pollutants,

Refractory natural pollutants, Heavy Metals (such as Mercury, Arsenic, Lead, Chromium etc.) also

Dissolved Inert Entities.

Bodily stuffs, chemical and organic traits of wastewaters are interconnected, e.g. bodily and chemical characteristics of water our bodies have an effect on the abundance, species composition, balance, productiveness and organic situations of populations of aquatic organisms. Concerning physical residences, as an example, temperature can also have an effect on the gases, and, in some cases, the dissolved inorganic solids. Any other belongings, turbidity is associated with suspended strong concentrations.

The pollution potential of wastewater is at once proportional to the pollutants concentration. The wastewater characterization allows establishment of the required remedy machine to make sure the standard of handled wastewater effluent.

\section{Literature review and process}

In this paper, I have considered two industries namely being my topic of interest:

Textile Industry

Tanneries

\section{Textile industry}

Textile Industry is one among the most important and oldest industries present globally. The industry provides jobs with no required special skills, which in turn plays a major role in providing employment in poor countries like Bangladesh, Vietnam, Sri Lanka and Mauritius. Therefore, it plays a dynamic role in the increase of GDP value of these countries. 
Textile industry is classified into 3 main categories:

Cellulose (which include cotton, rayon, linen, ramie, hemp and lyocell),

Protein (which includes wool, angora, mohair, cashmere and silk) and

Synthetic (includes polyester, nylon, spandex, acetate, acrylic, ingeo and polypropylene).

Colors and Chemicals utilized in the textile industries depends on manufactured fabrics. Reactive colors (remazol, Cibcron F and procion MX), naphthol colors (fast yellow $\mathrm{GC}$, fast scarlet $\mathrm{R}$ and fast blue $\mathrm{B}$ ), direct colors (direct yellow 50, Congo red and direct brown 116), and indigo colors (indigo white and indigo carmine) are some of the colors used to color cellulose fibers. Protein fibers are colored using acid colors (triarylmethane colors, azo colors and Anthraquinone colors) and Lanaset colors (Bordeaux B, Blue 5G). Other colors, like dispersed colors (Disperse yellow 218 and disperse navy 35), basic colors (basic orange 37 and basic red 1) and direct colors, are used to color synthetic fibers. Reactive colors are the foremost commonly used cellulose fiber color. Cotton, one of the most widely used fibers is colored mainly using reactive colors. The world use of reactive colors increased from 60,000 tons in 1988 to 178,000 tons in 2004. Cotton could also be colored using direct colors, indigo colors and naphthol colors.

High $\mathrm{pH}$ is found to denature proteins consequently corrosive colors are generally utilized protein strands. Compound responses between corrosive color and filaments are found to shape an insoluble color particle on the fiber. Lanaset colors are one of famous gathering of colors characterized under receptive and corrosive colors that color protein filaments. Usually Reactive colors are utilized to color protein filaments. Fleece, mohair, angora, cashmere and silk could be colored utilizing corrosive or responsive colors.

Most generally utilized manufactured textures color to color polyester, nylon or acetic acid derivations are Dispersed colors. Nylon strands are discovered to be viable when colored with direct colors. Essential colors are discovered to be a solid shading operator when utilized on acrylic fibers. Industries of Textile produce a lot of fluid squanders that contain natural and inorganic mixes. A few essential, optional and tertiary treatment measures have been utilized to treat these effluents. These included flocculation, synthetic coagulation, basic sedimentation, circulated air through tidal ponds, oxygen consuming initiated muck, streaming channels, invert assimilation and electro dialysis.

In any case, these aren't powerful against the expulsion, all things considered, and synthetic compounds utilized. These effluents contain high concentration of colors, yet in addition synthetics used at differed preparing stages. Some follow metals like $\mathrm{Cr}, \mathrm{Cu}, \mathrm{As}$, and Zinc are available in these gushing are equipped for causing a few medical conditions including nausea, hemorrhage, serious skin related issues.

Progressed oxidation measures (AOPs) created to get hydroxyl free extremists utilizing various oxidants under various blends. These radicals devastate parts that are not obliterated under regular oxidation measures. AOP utilizing ozone, photo phenton, $\mathrm{TiO}_{2}$, Ultraviolet, Fenton and peroxide are frequently wont to treat textile colors. The principle advantage of the treatment method is:

it's nature is of destructive type, 
Mineralization of the contaminants of organic type those are present in wastewater.

AOPs are considered as low or non-squander age advancements that wrecks complex structures utilizing fleeting compound species with a high oxidation power.

\section{Types of textiles and textile industries}

Various manufacturing processes are administered for various sorts of textiles. The process of production of textiles is broadly classified in two categories:

Spinning or the dry process

Wet process which involves usage of colors.

Creation of cotton textile includes the division of cotton strands from the cotton seeds which are then spun into cotton yarns. These yarns are meshed effectively into textile. The textile at that point go through different wet cycles including burning and scouring, hence utilizing huge measure of water.

Coloring is one among the preeminent significant strides inside the wet cycle which includes changing the shade of the material spun utilizing colors. Completing is that the last advance in assembling and uses synthetic compounds likes HS-ULTRAPHIL, ECODESIZE-PS-10 and Amino silicone liquid to treat the fabrics for acquiring an obviously better quality.

The initial phase in the creation of livestockshide items includes the expulsion of hair, between fibrillary protein and epidermis utilizing physical and mechanical strategies. The livestockshide is first treated with stomach related chemicals to eliminate the non-sinewy proteins and afterward absorbed sulphuric corrosive to bring down the $\mathrm{pH}$. At that point, it goes through tanning utilizing different kinds of tanning measure: mineral/chrome tanning, vegetable tanning and oil tanning. At last, the calfskin goes through coloring and completing cycles.

The creation of silks includes the extraction of silk strings from the cases. The strings have a glutinous substance which is taken out by washing and dying. The strings are then weaved and go through the withering cycle which gives the silks an alternate shade. After the coloring cycle, the strings go through the completing cycle.

Colors used in the textile manufacturing process: Different sorts of textile are colored utilizing various kinds of colors. Colors can be ordered into various kinds relying upon their substance organizations and properties. Accordingly, the utilization of colors differs from industry to industry contingent upon textures they produce.

Colors for cellulose fibers: Cellulose is comprised of rehashing glucose units. The most generally utilized color for cellulose textile is receptive colors. Different sorts of colors utilized are immediate colors, tank colors, Sulfur colors, indigo colors and naphthol colors.

Reactive colors: otherwise called fiber receptive colors are most significant coloring class for cellulosic filaments, used to color protein strands, for example, fleece and silk equipped for shaping covalent bonds with the fiber atom and viewed as best and lasting colors utilized. Found to figure well on any cellulose fiber under various temperatures. Receptive colors are of two sorts: homo bi functional and hetero bi functional.

Procion MX: is a cold water reactive color that could be utilized at ordinary room temperature. These fiber responsive colors are found to deliver shading inside fiber instead of on its surface, thus have light speed and 
wash speed. They are discovered to be brilliant for direct applications, printing, splash painting and submersions coloring techniques. Nonetheless, most usually utilized in tie coloring.

Cibcron F: another ordinarily utilized receptive colors. Not at all like procion MX colors, these colors could just work in a marginally hotter temperature $\left(40-48^{\circ} \mathrm{C}\right)$, stay dynamic and could be put away and utilized later. Cibcron F colors additionally are known to flexibly a straightforward wash quickness. Discovered to be successful on cellulose strands, fleece and silk.

Sabracron F: These are found to figure totally practically like Procion MX colors however must be used in a fairly hotter temperature of $\left(40-48{ }^{\circ} \mathrm{C}\right)$. Sabracron F colors are discovered to be minimal less receptive than Procion MX however they give an incredible wash quickness property. These colors are additionally found to color cellulose strands, fleece and silk.

Remazol: Remazol colors are fiber receptive colors that are utilized most ordinarily in painting silk. They can likewise be utilized to color cellulose strands and fleece. Remazol colors are a gaggle of colors that are discovered to be less respond capable contrasted with the inverse receptive colors like procion MX, which makes them more steady in water than procion MX

Direct Colors: Direct colors are applied under a fluid shower containing electrolytes and ionic salts. These colors don't shape solid bonds and are inexactly connected with the fiber atoms these colors are applied under temperatures of $79.4-93.3{ }^{\circ} \mathrm{C}$. Direct colors are utilized for coloring rayon, material and cellulosic filaments; they could likewise be utilized to color fleece and silk by utilizing synthetic fixative specialists. Favorable circumstances of these colors is that they are the least expensive among every single other color

Indigo: Indigo might be a naval force glasslike powder that is insoluble in water. Diminishing operators like sodium hydrosulfite make it solvent in water. Ordinarily, indigo colors don't have a fondness towards cotton, yet in a diminished state they will in general enter the space in the cotton filaments. The color particles inside the fiber are then presented to air, which makes it insoluble again and effectively caught inside the fiber. These colors are the essential shade of Levis.

Naphthol: colors made with combination of two different chemicals: the diazo salts and the naphthol. This combination determines the color of the color. This color is treated as a cold water color. The temperature of cold water used with other groups of colors may range from 35 to $41^{\circ} \mathrm{C}$ but this type of color can be used even with ice water. Rayon, cotton or other cellulosic fibers as well as silk could be colored using naphthol colors.

Colors for protein fibers: Protein fibers are all of the fibers that are obtained from the animals (such as wool and silk). High $\mathrm{pH}$ denatures all denaturing proteins and the acid colors are, therefore, wont to color wool, angora, cashmere and the silk thus, applied to respective fabrics along with the acid solutions.

Azo colors: Azo tones represent $60-70 \%$ of all the shading gatherings and are found to offer out brilliant and extreme focus tones contrasted with the contrary classes of tones found to contain two groups:

the chromophore and the auxochrome 
Cotton generally, isn't found to bind well with acid or other anionic or cationic colors thanks to the presence of hydroxylic groups in its structure. Hence, simple azo colors are found to be not that effective in coloring cotton.

Triarylmethane colors: Triarylmethane colors are the derivatives of tri-aryl-methane hydrocarbon. Acidic triarylmethane colors containing at least two $\mathrm{SO} 3 \mathrm{H}$ group are wont to color wool and silk fibers. Colors containing just one $\mathrm{SO} 3 \mathrm{H}$ group are used as indicators (E.g. phenolphthalein). Basic triarylmethane colors are used extensively within the manufacture of stamping inks, writing and printing.

Anthraquinone colors: Anthraquinone colors have a sulphonic corrosive gathering which makes them solvent in water. They're wont to shading fleece and silk on account of their partiality towards helper restricting specialists. A subclass of shading called shading tones is wont to shading protein strands and a couple of nylon filaments under warmth. Anthraquinone color's another subclass is named as the fiber reactive color that is employed to color protein fibers. The foremost important and distinguishing characteristics of those colors are the property of forming covalent bonds during the appliance process with the substrates that's to be colored. Unlike other color groups, these colors contain a known chromophore system which contains various reactive groups. Based on these reactive groups, they're classified into:

Mono-anchor colors,

Double-anchor colors

And the Multiple-anchor colors

Colors for synthetic fiber: The generally utilized colors for manufactured fiber are scattered colors. These colors are chiefly used in the Printing of polyesters, nylon and acetic acid derivations. Some scattered colors likewise are utilized as printer's ink in businesses. Scattered colors are arranged into three sorts upheld their energy.

The E type (which is low in energy) is employed in the thermosol coloring.

The $\mathrm{S}$ type (which is high in energy) is employed in High temperature/pressure coloring.

SE type is convenient for all coloring methods.

Majority of strong squanders originates from the dry processes while the wet one yields only a little amount of strong squanders.

Most of strong squanders are made of bits of textures and bundling textile. The evaporated slime from the material creation is additionally a significant wellspring of strong waste. Strong squanders are not discovered to be unsafe when all is said in done. Be that as it may, the exhausted synthetic compartments may contain hints of unsafe substances. Sources and kinds of strong squanders delivered in mechanical activities and coloring and completing tasks.

Most of the cycles being directed in material businesses produce vaporous discharges. Boilers, broilers and capacity tanks are the three most significant wellsprings of air contamination in the material business. The boilers create Sulfur-oxides and nitrogen. The high temperature material drying measure radiates hydrocarbons. Poisons additionally are produced from buildups of fiber planning during the glow settling measure. Gases can likewise be transmitted from synthetics during the coloring cycle.

Environmental Impacts of Textile Effluent: The attributes of material effluents change and rely on such a material fabricated and accordingly the synthetic compounds utilized. 
The textile wastewater effluent contains:

Large quantity of agents (in form of suspended, dissolved solids), Biological Oxygen Demand (BOD) Chemical Oxygen Demand (COD), Other chemicals, Odor and color.

Generally, BOD: COD proportions are discovered to be around 1:4, subsequently demonstrating presence of non-biodegradable substances. The material effluents contain follow metals like $\mathrm{Cr}$, $\mathrm{As}, \mathrm{Cu}$ and $\mathrm{Zn}$, which are fit for hurting the climate.

Colors in water give out frightful shading and may cause sicknesses like discharge, and different skin issues and can hinder the infiltration of daylight from water surface forestalling photosynthesis. Colors likewise increment the BOD of the accepting water and progressively diminish the reoxygenation cycle and henceforth hamper the development of photoautotrophic living beings. The suspended strong fixations inside the effluents assume vital function in influencing the climate as they consolidate with sleek rubbish and meddle.

\section{Tanneries}

The worldwide interest for leather, leather items increment step by step, since the worldwide populace and the way of life of individuals increment quickly consistently. During the 1970s, sending out stows away and skins were considered as expected wellspring of acquiring unfamiliar trade and neighborhood work. The majority of the cowhide makers confronted a cut in their profits because of the move of the worldwide tanning industry to the non-industrial nations. Simultaneously agricultural nations expanded in producing unfamiliar trade and nearby work. Regardless of this turn of events, natural contamination made by these production lines is sizable, uncovering tannery laborers and neighborhood networks to extreme wellbeing risks. Tanning is a basic a piece of the technique for changing over crude stows away and skins into completed cowhide. It includes three sorts of items, viz. crude to end; crude to semi-finish; and semifinish to wrap up. Cowhide creation innovation has advanced from the business to a completely motorized industry.

The leather and livestock hide items area presently speaks to one among the premier significant areas in India, adding to economy. The business has gone through a basic change during the most recent thirty years, from simply an exporter of staple inside the sixties thereto valuable added items possessing a position of noticeable quality inside the Indian economy as far as unfamiliar exchange, work age and development and is among the most noteworthy ten trade workers for the nation.

Creation of livestock hide in India has been firmly identified with the domesticated animal's populace. India being the nation with the biggest animals' populace has all the way to be the main maker of calfskin on the planet. India has one of the biggest livestock's populace on the planet. Yet, its offer on the planet exchange livestock hide is simply 3.5 percent, regardless of a few great variables, for example, solid crude material base, immense modest workforce and exceptionally created uphold ventures like synthetic compounds. This is a result of the absence of co-appointment among the slaughterhouses and tanneries, wasteful strategy for assortment of remains and conventional technique for relieving the calfskin.

Leather Industry and Waste Water: In leather manufacturing, the most outstanding process is tanning. Specific Requirements of tanneries: 
Raw material (hide, fell or skin) and

The tanning system, which depends on the tanning substance (mineral or organic nature).

Classification according to stages of production:

Complete tanneries, starts from raw hide to produce finished leather.

Beam-house tanneries, starts from raw hide up to tanning step

Wet-end and finishing tanneries, starts from leather (wet-blue) to produce crust or finished leather.

The creation of completed calfskin from crude covers up and skins can be gathered under three significant tasks,

beam house

tanning and

Post- tanning operations.

The phases of shroud readiness (cleaning and molding treatment for tanning), likewise on the grounds that the transportation and obsession of tanning and adjusting substances into collagen structure are completely done in fluid media. Large portions of the means in these cycles are completed with new water, which is utilized as vehicle for dissemination of substance items and extraction of unfortunate material from the cover up.

Leather Production in India: Major production centers for leather and leather products in India are located in

Tamil Nadu region 6 cities namely Chennai, Ambur, Ranipet, Vaniyambadi, Trichy and Dindigul;

West Bengal region it's in Kolkata;

Uttar Pradesh region 3 cities Kanpur, Agra and Noida;

Maharashtra region it is in Mumbai;

Punjab existing in Jalandhar;
Karnataka it's in Bangalore;

Andhra Pradesh, Hyderabad;

Haryana region 4 cities Ambala, Gurgaon, Panchkula, Karnal;

And in Delhi.

\section{Process stages}

According to the Reports of the Central Leather Research Institute and the State Pollution Control Board, Chennai, the number of tanneries situated in India is given below along with its percentages

The processing of raw (green, chilled or chemically cured) and salted (dry or wet salted) hides and skins is divided into two sections, namely, the beam house and the tan yard section, with numerous processing occurring in each of the section:

\section{Beam house (or lime yard) section}

Soaking: It once again introduces water into the covers up and skins, cleans out any additives (typically salt), blood, fertilizer, pee and earth, and relax the stows away and skins for ensuing handling.

Green fleshing: Fleshing is the mechanical ejection of fats and tissue from inside stows away or skins. Fleshing can be refined beforehand or in the wake of liming, and there are focal points and shortcomings to each. From a characteristic perspective, green fleshing is best as the tissue isn't dirtied with engineered materials, and the proportion of artificial materials needed for unhairing and liming are lessened. This reduces the proportion of engineered substances in the exuding from downstream cycles.

Liming and Unhairing: Unhairing and liming measures are generally done at the same time. Synthetic substances are utilized to: 
Partially hydrolyze polypeptides to relax structure of hide/skin.

Soluble globular proteins.

Sponify fats.

Swell hides.

In case of sheepskins, wool can be recovered as byproduct by the process known as paint unhairing.

Lime fleshing: Lime fleshing is like green fleshing, yet it happens subsequent to unhairing and liming. The nature of escapes lime fleshing is regularly better than those created utilizing green fleshing. Lime fleshing is the technique for decision in tanneries.

Lime splitting and trimming: Splitting is a type of managing where the cover up is precisely partitioned into a grain layer and a substance layer. This can be cultivated in the wake of liming or chromium tanning. A few decorations may likewise be handled to livestockshide. Lime parting diminishes the measure of synthetic compounds needed in downstream cycles. Parting and shaving are generally performed subsequent to tanning.

\section{De-liming and bating}

These are the processes that use the chemicals and the enzymes

It removes the residual chemicals also reduces the livestock's hides and livestock's skins $\mathrm{pH}$ value.

It also softens the livestock's hides \& skins to assist penetration of chemicals in ensuing process stages.

\section{Tan yard section}

Degreasing: Excessive amounts of grease in the hide or skin may cause non-uniform penetration of $\tan$ or color. This causes complications with the finishing processes and creates dark and greasy patches on the finished leather. Degreasing is particularly important before chrome tanning as chromium salts can react with the greases and form insoluble chromium soaps, which are very difficult to remove.

Pickling: Pickling is a chemical process whereby:

To lower the $\mathrm{pH}$ to $2-3$, acids are added for better penetration of tanning synthetics.

Adding Salt for hide prevention from swelling under the acidic conditions.

In the case of pickled sheepskins, the picking process preserves the skin and is the final processing step.

Tanning: It is cultivated by adding tanning synthetics into a drum containing the stows away for a proper time span. A large portion of the 'leather' is exchanged as wet blue. On account of wet blue, the tanning specialist is trivalent chrome tanning salts. On account of wet white or without metal calfskin, glutaraldehyde is utilized as tanning compound. It should be focused on that tanneries just utilize trivalent chromium, that has been discovered to be non-harmful.

Basification: The adding of a gentle soluble base into the tanning drums to guarantee authoritative of the tanning substance to the livestock hide/skin. Subsequent to tanning, a last wash is done to eliminate any unbound synthetic compounds from livestock hide/skin. 
Table.1 Types of waste produced from different processes[2]

\begin{tabular}{|c|c|c|c|}
\hline Process & Emission & Wastewater & Solid Wastes \\
\hline Fibre preparation & Little or none & Little or none & Fibre waste and packaging waste \\
\hline Yam spinning & Little or none & Little or none & $\begin{array}{l}\text { Packaging wastes, sized yam, fibre waste, cleaning } \\
\text { and processing waste }\end{array}$ \\
\hline Slashing/sizing & vocs & $B O D, C O D$, metals, cleaning waste, size & $\begin{array}{l}\text { Fibre lint, yarn waste, packaging waste, unused } \\
\text { starch-based sizes }\end{array}$ \\
\hline Weaving & Little or none & Little or none & $\begin{array}{l}\text { Packaging waste yam and fabric scraps, off - spec } \\
\text { fabric, used oil }\end{array}$ \\
\hline Knitting & Little or none & Little or none & Packaging waste, yarn, fabric scraps. \\
\hline Tufting & Little or none & Little or none & Packaging waste, yarn, fabric scraps, off-spec fabric \\
\hline Desizing & VOCs from glycol esters & $\begin{array}{l}\text { BOD from sizes lubricants, biocides, anti-static } \\
\text { compounds }\end{array}$ & $\begin{array}{l}\text { Packaging waste, fibre lint, yarn waste, cleaning } \\
\text { and maintenance materials }\end{array}$ \\
\hline Scouring & $\begin{array}{l}\text { VOCs from glycol ester and scouring } \\
\text { solvents }\end{array}$ & $\begin{array}{l}\text { Disinfectants, insecticide recisues, } \\
\mathrm{NaOH} \text {, detergents oils, knitting lubricants, spin } \\
\text { finishes,spent solvents }\end{array}$ & Little or none \\
\hline Bleaching & Little or none & $\mathrm{H}_{2} \mathrm{O}_{2}$, stabilizers, high pH & Little or none \\
\hline Singeing & $\begin{array}{l}\text { Small amount of exhaust gases from the } \\
\text { bumers exhausted with components }\end{array}$ & Little or none & Little or none \\
\hline Mercerising & Little or none & High pH, NaOH & Little or none \\
\hline Heat setting & $\begin{array}{l}\text { Volatilisation of spin finish agents-synthetic } \\
\text { fibre manufacture }\end{array}$ & Little or none & Little or none \\
\hline Dyeing & vocs & $\begin{array}{c}\text { Metals, salt, surfactants, organic } \\
\text { processing } \\
\text { assistants, cationic materials, colour, BOD, } \\
\text { COD, sulphide, acidityfalkalinity, spent solvents }\end{array}$ & Little or none \\
\hline Printing & $\begin{array}{l}\text { Solvents, acetic acid-drying and curing oven } \\
\text { emission combustion gases }\end{array}$ & $\begin{array}{c}\text { Suspended solids, urea, solvents, colour, metals, } \\
\text { heat, BOD, foam }\end{array}$ & Little or none \\
\hline Finishing & $\begin{array}{l}\text { VOCs, contaminants in purchased } \\
\text { chemicals, formaldehyde vapours, } \\
\text { combustion gases }\end{array}$ & $\begin{array}{c}\mathrm{COD} \text {, suspended solids, toxic materials, spent } \\
\text { solvents }\end{array}$ & Fabric scraps and trimmings, packaging waste \\
\hline
\end{tabular}

\section{Table.2(a): Water consumption by processing of different fabrics.}

\begin{tabular}{|c|c|c|c|}
\hline \multirow{2}{*}{ Processing Subcategory } & \multicolumn{3}{|c|}{ Water Consumption ( $\mathrm{m}^{3} /$ ton fibre material) } \\
\hline & Minimum & Median & Maximum \\
\hline Wool & 111 & 285 & 659 \\
\hline Woven & 5 & 114 & 508 \\
\hline Knit & 2 & 84 & 377 \\
\hline Carpet & 8.3 & 47 & 163 \\
\hline Stock/yarn & 3.3 & 100 & 558 \\
\hline Nonwoven & 2.5 & 40 & 83 \\
\hline Felted fabric finishing & 33 & 213 & 933 \\
\hline
\end{tabular}

\section{Table.2(b): Water consumed by different} process.

\begin{tabular}{|c|c|}
\hline Process & $\begin{array}{c}\text { Water Consumed } \\
(\mathbf{\%})\end{array}$ \\
\hline Bleaching & 38 \\
\hline Dyeing & 16 \\
\hline Printing & 8 \\
\hline Boiler & 14 \\
\hline Other uses & 24 \\
\hline
\end{tabular}

\section{Table.2(d): Water requirements for various process}

\begin{tabular}{|c|c|c|c|c|c|}
\hline \multirow{2}{*}{ Process } & \multicolumn{5}{|c|}{$\begin{array}{c}\text { Water Requirements } \\
\text { (L1000 kg of products) }\end{array}$} \\
\cline { 2 - 6 } & Rayon & Acetate & Nylon & $\begin{array}{c}\text { Acrylicl } \\
\text { Modacrylic }\end{array}$ & Polyester \\
\hline Scouning & $17000-34000$ & $25000-84000$ & $50000-67000$ & $50000-67000$ & $25000-42000$ \\
\hline Salt bath & $4000-12000$ & - & - & - & - \\
\hline Bleaching & - & $33000-50000$ & - & - & - \\
\hline Dyeing & $17000-34000$ & $34000-50000$ & $17000-34000$ & $17000-34000$ & $17000-34000$ \\
\hline $\begin{array}{c}\text { Special } \\
\text { finishing }\end{array}$ & $4000-12000$ & $24000-40000$ & $32000-48000$ & $40000-56000$ & $8000-12000$ \\
\hline
\end{tabular}

\section{Table.2(c): Water consumed by different} process in tanning.

\begin{tabular}{|c|c|}
\hline Process & $\begin{array}{c}\text { Water Consumption } \\
\text { (L/1000 kg of products) }\end{array}$ \\
\hline Sizing & $500-8200$ \\
\hline Desizing & $2500-21000$ \\
\hline Scouring & $20000-45000$ \\
\hline Bleaching & $2500-25000$ \\
\hline Mercerizing & $17000-32000$ \\
\hline Dyeing & $10000-300000$ \\
\hline Printing & $8000-16000$ \\
\hline
\end{tabular}

\section{Table.2(e): Chemical requirement during} bleaching

\begin{tabular}{|c|c|c|}
\hline \multirow{2}{*}{ Chemical } & \multicolumn{2}{|c|}{$\begin{array}{c}\text { Utilization } \\
\text { (kg/100kg of cloth) }\end{array}$} \\
\hline & Soft Flow Machine & Winch \\
\hline Wetting agent & 0.5 & 0.5 \\
\hline Caustic soda & 2.5 & 4.0 \\
\hline Peroxide & 3.0 & 4.0 \\
\hline Lubricants & 0.2 & 0.3 \\
\hline Stabilizers & 0.2 & 0.3 \\
\hline Peroxide killer (oxidizing agent) & 1.0 & 1.0 \\
\hline Acetic acid & 2.0 & 2.0 \\
\hline
\end{tabular}




\begin{tabular}{|c|c|c|c|c|}
\hline \multicolumn{3}{|c|}{$\begin{array}{c}\text { Table.3(a): Overall Chemical Requirement } \\
\text { During Dying. }\end{array}$} & \multicolumn{2}{|c|}{$\begin{array}{c}\text { Table.3(b): Solid Waste Generated From } \\
\text { Different Sources. }\end{array}$} \\
\hline \multirow[t]{2}{*}{ Chemicals } & \multicolumn{2}{|c|}{$\begin{array}{c}\text { Utilization } \\
(\mathrm{kg} / 100 \mathrm{~kg} \text { of cloth) }\end{array}$} & \begin{tabular}{|l|} 
Source \\
Mechanical operations of cotton and synthetics \\
\end{tabular} & Type of Solid Waste \\
\hline & Soft Flow & Winch & Yam preparation & Fibres and yarns \\
\hline Lubricants (kg) & 0.3 & 0.4 & Knitting & Fibres and yarns \\
\hline Sequestering agent (kg) & 0.6 & 1.0 & Weaving & Fibres, yarns and cloth \\
\hline Dye stuff (kg) & & & 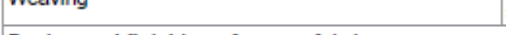 & scraps \\
\hline Light Shade & 0.150 & 0.150 & \multicolumn{2}{|l|}{ Dyeing and finishing of woven fabrics } \\
\hline Medium Shade & 1.5 & 1.5 & $\begin{array}{l}\text { Sizing, desizing, mercerizing, beaching, washing and } \\
\text { chemical finishing }\end{array}$ & Cloth scraps \\
\hline Dark Shade & 10.0 & 10.0 & Mechanical finishing & Flock \\
\hline Soda ash $(g / L)$ & & & Dyeing/printing & Dye containers \\
\hline Light Shade & 6.0 & 6.0 & Dyeing/printing (applied finish) & Chemical containers \\
\hline $\begin{array}{l}\text { Medium Shade } \\
\text { Dark Shade }\end{array}$ & $\begin{array}{l}11.0 \\
20.0\end{array}$ & $\begin{array}{l}11.0 \\
20.0\end{array}$ & Dyeing and finishing of knitted fabrics & $\begin{array}{l}\text { Cloth scraps, dye and } \\
\text { chemical containers }\end{array}$ \\
\hline Sodium chloride $(g / L)$ & & & \multicolumn{2}{|l|}{ Dyeing and finishing of carpets } \\
\hline Light Shade & 15.0 & 15.0 & Tufting & Yarns and sweepings \\
\hline Medium Shade & 45.0 & 45.0 & Selvage trim & Selvage \\
\hline Dark Shade & 90.0 & 90.0 & Fluff and shear & Flock \\
\hline Acetic acid $(\mathrm{kg})$ & 2.5 & 3.0 & \multirow[t]{3}{*}{ Dyeing, printing and finishing } & \multirow{2}{*}{$\begin{array}{l}\text { Dye and chemical } \\
\text { containers }\end{array}$} \\
\hline Soap $(\mathrm{kg})$ & 1.0 & 1.0 & & \\
\hline Fixing $(\mathrm{kg})$ & 1.0 & 1.0 & & \\
\hline Softener $(\mathrm{kg})$ & 2.0 & 2.0 & & \\
\hline
\end{tabular}

\begin{tabular}{|c|c|c|c|c|}
\hline \multicolumn{3}{|c|}{$\begin{array}{c}\text { Table.3(c): Pollutants Emitted From } \\
\text { Different Process. }\end{array}$} & \multicolumn{2}{|c|}{$\begin{array}{c}\text { Table.3(d): Characteristics Of Typical } \\
\text { Untreated Textile Wastewater }\end{array}$} \\
\hline Process & Source & Pollutants & Parameter & Range \\
\hline \multirow{3}{*}{ Energy production } & \multirow{3}{*}{ Emission from boiler } & \multirow{3}{*}{$\begin{array}{l}\text { Particulates, nitrous } \\
\text { oxides(Nox), sulphur dioxide } \\
\left(\mathrm{SO}_{2}\right)\end{array}$} & $\mathrm{pH}$ & $6-10$ \\
\hline & & & Temperature $\left({ }^{\circ} \mathrm{C}\right)$ & $35-45$ \\
\hline & & & Total dissolved solids (mg/L) & $8,000-12,000$ \\
\hline \multirow{2}{*}{$\begin{array}{l}\text { Coating, drying and } \\
\text { curing }\end{array}$} & \multirow{2}{*}{$\begin{array}{l}\text { Emission from high } \\
\text { temperature ovens }\end{array}$} & \multirow{2}{*}{$\begin{array}{l}\text { Volatile organic components } \\
\text { (VOCs) }\end{array}$} & BOD $(\mathrm{mg} / \mathrm{L})$ & $80-6,000$ \\
\hline & & & $\operatorname{COD}(\mathrm{mg} / \mathrm{L})$ & $150-12,000$ \\
\hline \multirow{3}{*}{$\begin{array}{l}\text { Cotton handling } \\
\text { activities }\end{array}$} & \multirow{3}{*}{$\begin{array}{l}\text { Emission from } \\
\text { preparation, carding, } \\
\text { combing and fabrics } \\
\text { manufacturing }\end{array}$} & \multirow{3}{*}{ Particulates } & Total suspended solids $(\mathrm{mg} / \mathrm{L})$ & $15-8,000$ \\
\hline & & & Total Dissolved Solids (mg/L) & $2,900-3,100$ \\
\hline & & & Chlorine $(\mathrm{mg} / \mathrm{L})$ & $1,000-6,000$ \\
\hline \multirow{3}{*}{ Sizing } & \multirow{3}{*}{$\begin{array}{l}\text { Emission from using } \\
\text { sizing compound } \\
\text { (gums, PVA) }\end{array}$} & \multirow{3}{*}{$\begin{array}{l}\text { Nitrogen oxides, sulphur oxide, } \\
\text { carbon monoxide }\end{array}$} & Free chlorine $(\mathrm{mg} / \mathrm{L})$ & $<10$ \\
\hline & & & Sodium $(\mathrm{mg} / \mathrm{L})$ & $70 \%$ \\
\hline & & & Trace elements (mg/L) & \\
\hline \multirow{2}{*}{ Bleaching } & \multirow{2}{*}{$\begin{array}{l}\text { Emission from using } \\
\text { chlorine compound }\end{array}$} & \multirow{2}{*}{ Chlorine, chlorine dioxide } & $\mathrm{Fe}$ & $<10$ \\
\hline & & & $\mathrm{Zn}$ & $<10$ \\
\hline \multirow{3}{*}{ Dyeing } & \multirow{3}{*}{$\begin{array}{l}\text { Disperse dyeing using } \\
\text { carriers sulphur dyeing } \\
\text { Aniline dyeing }\end{array}$} & \multirow{3}{*}{$\begin{array}{c}\text { Carriers } \\
\mathrm{H}_{2} \mathrm{~S} \\
\text { Aniline vapours } \\
\end{array}$} & $\mathrm{Cu}$ & $<10$ \\
\hline & & & As & $<10$ \\
\hline & & & $\mathrm{Ni}$ & $<10$ \\
\hline \multirow{3}{*}{ Finishing } & Emission & Hydrocarbons, ammonia & B & $<10$ \\
\hline & \multirow{2}{*}{$\begin{array}{l}\text { Resin finishing heat } \\
\text { setting of synthetic } \\
\text { fabrics }\end{array}$} & \multirow{3}{*}{$\begin{array}{c}\text { Formaldehydes } \\
\text { Carriers - low molecular weight } \\
\text { Polymers- lubricating oils }\end{array}$} & $\mathrm{F}$ & $<10$ \\
\hline & & & Mn & $<10$ \\
\hline \multirow{3}{*}{ Chemical storage } & \multirow{3}{*}{$\begin{array}{l}\text { Emission from storage } \\
\text { tanks for commodity } \\
\text { and chemicals }\end{array}$} & & $\mathrm{v}$ & $<10$ \\
\hline & & \multirow{2}{*}{$\begin{array}{l}\text { Volatile organic components } \\
\text { (VOCs) }\end{array}$} & $\mathrm{Hg}$ & $<10$ \\
\hline & & & $\mathrm{PO}_{4}$ & $<10$ \\
\hline \multirow{3}{*}{ Waste water treatment } & \multirow{3}{*}{$\begin{array}{l}\text { Emission from } \\
\text { treatment tanks and } \\
\text { vessels }\end{array}$} & \multirow{3}{*}{$\begin{array}{l}\text { Volatile organic components, } \\
\text { toxic emissions }\end{array}$} & $\mathrm{Cn}$ & $<10$ \\
\hline & & & Oil \& grease (mg/L) & $10-30$ \\
\hline & & & TNK (mg/L) & $10-30$ \\
\hline & & & $\mathrm{NO}_{3}-\mathrm{N}(\mathrm{mg} / \mathrm{L})$ & $<5$ \\
\hline & & & Free ammonia (mg/L) & $<10$ \\
\hline & & & $\mathrm{SO}_{4}(\mathrm{mg} / \mathrm{L})$ & $600-1000$ \\
\hline & & & Silica (mg/L) & $<15$ \\
\hline & & & Total Kjeldahl Nitrogen $(\mathrm{mg} / \mathrm{L})$ & $70-80$ \\
\hline & & & Color $(\mathrm{Pt}-\mathrm{Co})$ & $50-2,500$ \\
\hline
\end{tabular}




\begin{tabular}{|c|c|c|c|c|}
\hline \multicolumn{3}{|c|}{$\begin{array}{c}\text { Table.4(a): Sources Of Water Pollution At } \\
\text { Various Stages Of Processing. }\end{array}$} & \multicolumn{2}{|c|}{$\begin{array}{l}\text { Table.4(b): Toxic Aromatic Amines } \\
\text { Derivatives From Azo Colors. }\end{array}$} \\
\hline Process & Possible Pollutants & Nature of Effluent & Aromatic Amine Group & Human Carcinogenic Evidences \\
\hline \multirow{2}{*}{ Desizing } & \multirow{2}{*}{$\begin{array}{l}\text { Starch, glucose, PVA, resins, fats } \\
\text { and waxes do not exert a high } \\
\text { BOD. }\end{array}$} & \multirow{2}{*}{$\begin{array}{l}\text { Very small volume, high BOD } \\
\text { (30-50\% of total), PVA. }\end{array}$} & 1-Napthylamine & Slight/Mixed \\
\hline & & & 2-Napthylamine & Good \\
\hline \multirow{3}{*}{ Kiering } & \multirow{3}{*}{$\begin{array}{l}\text { Caustic soda, waxes, soda ash, } \\
\text { sodium silicate and fragments of } \\
\text { cloth. }\end{array}$} & \multirow{3}{*}{$\begin{array}{c}\text { Very small, strongly alkaline, } \\
\text { dark colour, high BOD values } \\
\text { ( } 30 \% \text { of total) }\end{array}$} & 2,5-Diaminotoluene & Slight \\
\hline & & & 3,3'-Dichlorobenzidine & Slight/Mixed \\
\hline & & & 3,3'-Dimethoxybenzidine & Slight/Mixed \\
\hline \multirow{2}{*}{ Bleaching } & \multirow{2}{*}{$\begin{array}{c}\text { Hypochlorite, chlorine, caustic } \\
\text { soda, hydrogen peroxide, acids. }\end{array}$} & \multirow{2}{*}{$\begin{array}{c}\text { Small volume, strongly alkaline, } \\
\text { low BOD ( } 5 \% \text { of total) }\end{array}$} & 3,3'-Dimethylbenzidine & Slight \\
\hline & & & 4-Biphenylamine & Good \\
\hline \multirow{2}{*}{ Mercerizing } & \multirow{2}{*}{ Caustic soda } & \multirow{2}{*}{$\begin{array}{c}\text { Small volume, strongly alkaline, } \\
\text { low BOD (Less than } 1 \% \text { of } \\
\text { total) }\end{array}$} & 4-Nitrobiphenyl & Slight/Mixed \\
\hline & & & 4,4-Methylenebis (2-chloroaniline) & Slight \\
\hline \multirow{3}{*}{ Dyeing } & \multirow{3}{*}{$\begin{array}{l}\text { Dye stuff, mordant and reducing } \\
\text { agents like sulphides, acetic acids } \\
\text { and soap }\end{array}$} & \multirow{3}{*}{$\begin{array}{l}\text { Large volume, strongly } \\
\text { coloured, fairly high BOD ( } 6 \% \\
\text { of total) }\end{array}$} & Auramine & Slight \\
\hline & & & Benzidine & Good \\
\hline & & & Magenta & Slight \\
\hline \multirow{2}{*}{ Printing } & \multirow{2}{*}{$\begin{array}{c}\text { Dye, starch, gum oil, china clay, } \\
\text { mordants, acids and metallic salts }\end{array}$} & \multirow{2}{*}{$\begin{array}{c}\text { Very small volume, oily } \\
\text { appearances, fairly high BOD. }\end{array}$} & N-Phenyl-2-napthylamine & Slight \\
\hline & & & $\mathrm{N}, \mathrm{N}$-Bis(2-chloroethyl)-napthylamine & Good \\
\hline Finishing & $\begin{array}{c}\text { Traces of starch, tallow, salts, } \\
\text { special finishes, etc. }\end{array}$ & $\begin{array}{l}\text { Very small volume, less } \\
\text { alkaline, low BOD. }\end{array}$ & & \\
\hline \multicolumn{3}{|c|}{$\begin{array}{l}\text { PVA - Poly Vinyl Alcohol } \\
\text { BOD - Biological Oxygen Demand } \\
\text { COD - Chemical Oxygen Demand }\end{array}$} & & \\
\hline
\end{tabular}

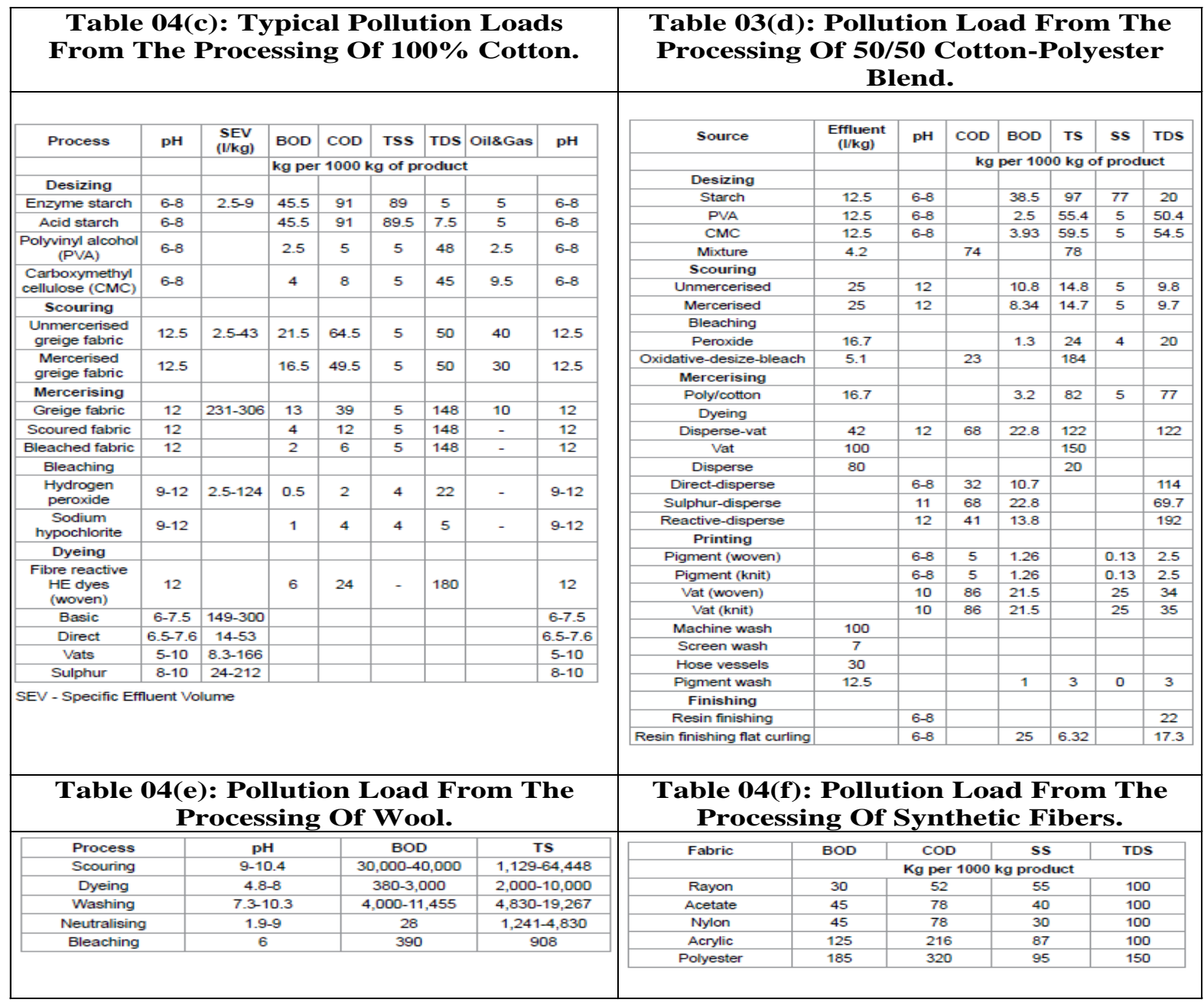


Table.5 Number of tanneries across states

\begin{tabular}{|c|c|c|c|}
\hline Sl.no & States & Number of Tammeries & Percentage Share \\
\hline 1 & Tamil Nadu & 934 & 44.67 \\
\hline 2 & West Bengal & 538 & 25.73 \\
\hline 3 & Punjab & 79 & 3.78 \\
\hline 4 & Utter Pradesh & 378 & 18.08 \\
\hline 5 & Andhra Pradesh & 24 & 1.15 \\
\hline 6 & Maharashtra & 33 & 1.58 \\
\hline 7 & Karnataka & 16 & 0.77 \\
\hline 8 & Bihar & 17 & 0.80 \\
\hline 9 & Haryana & 18 & 0.86 \\
\hline 10 & Rajasthan & 15 & 0.72 \\
\hline 11 & Other States & 39 & 1.86 \\
\hline & Total & $\mathbf{2 , 0 9 1}$ & $\mathbf{1 0 0 . 0 0}$ \\
\hline
\end{tabular}

Source: Compiled from the Records of the Central Leather Research Institute,

Chennai, 2007; and State Pollution Control Board, Chennai, 2007.

\begin{tabular}{|c|c|c|}
\hline \multicolumn{3}{|c|}{ Table 06: Processes under Wet blue and Color house Stages } \\
\hline Process & Chemicals & Purpose \\
\hline \multicolumn{3}{|c|}{ Wet blue process stages } \\
\hline Soaking & $\begin{array}{l}\text { Biocides, surfactants, degreasers, } \\
\text { enzymes }\end{array}$ & $\begin{array}{l}\text { Reintroduce water and washing of } \\
\text { chemicals and dirt }\end{array}$ \\
\hline $\begin{array}{l}\text { Liming and } \\
\text { unhairing }\end{array}$ & $\begin{array}{l}\text { Lime, sodium sulphide, sodium } \\
\text { hydrosulphide, caustic soda }\end{array}$ & Chemically remove hair and swell skins \\
\hline $\begin{array}{l}\text { Deliming and } \\
\text { bating }\end{array}$ & $\begin{array}{l}\text { Ammonium sulphate, ammonium chloride, } \\
\text { formic acid, proteolytic enzymes }\end{array}$ & $\begin{array}{l}\text { Remove lime and calcium } \\
\text { Lower } \mathrm{pH} \\
\text { Soften hide }\end{array}$ \\
\hline Pickling & $\begin{array}{l}\text { Salt, sulphuric acid, formic acid, sodium } \\
\text { formate, fungicide }\end{array}$ & $\begin{array}{l}\text { Lower } \mathrm{pH} \text { of the hide or skin to allow } \\
\text { proper penetration of tanning chemicals }\end{array}$ \\
\hline Tanning & $\begin{array}{l}\text { Trivalent chrome tanning salts (wet blue) or } \\
\text { glutaraldehyde (wet white) }\end{array}$ & Tanning \\
\hline Basification & Magnesium oxide and sodium bicarbonate & $\begin{array}{l}\text { Ensure binding of tanning chemicals to } \\
\text { hide or skin }\end{array}$ \\
\hline \multicolumn{3}{|c|}{ Dyehouse process stages } \\
\hline Washing & Surfactants & $\begin{array}{l}\text { Reintroduce water } \\
\text { Soften and remove shavings, oils or } \\
\text { greases }\end{array}$ \\
\hline Neutralisation & Sodium bicarbonate, sodium formate & Increase $\mathrm{pH}$ to allow chemical penetration \\
\hline Retanning & Syntans, resins, vegetable tannins & Give specific leatherlike properties \\
\hline Dyeing & Dyestuffs & Give the desired colour \\
\hline Fatliquoring & Fatliquors (emulsified oils) & Soften leather and make it flexible \\
\hline Fixation & Formic acid & $\begin{array}{l}\text { Lower } \mathrm{pH} \text { to ensure chemical binding of } \\
\text { the chemicals in the previous steps }\end{array}$ \\
\hline
\end{tabular}




\begin{tabular}{|c|c|c|c|c|c|c|c|c|c|c|}
\hline \multirow[t]{2}{*}{ Operation } & \multirow{2}{*}{$\begin{array}{l}\text { Techno- } \\
\text { logy }\end{array}$} & \multicolumn{9}{|c|}{ Pollution load (kg/t raw hide) } \\
\hline & & SS & $\mathrm{COD}$ & $\mathrm{BOD}_{5}$ & $\mathrm{Cr}$ & $\mathrm{S}^{2}$ & $\mathrm{NH}_{3}-\mathrm{N}$ & TKN & $\mathrm{Cl}^{-}$ & $\mathrm{SO}_{4}{ }^{2=}$ \\
\hline \multirow[t]{2}{*}{ Soaking } & $\mathrm{C}$ & $11-17$ & $22-33$ & $7-11$ & - & - & $0.1-0.2$ & $1-2$ & $85-113$ & $1-2$ \\
\hline & $\mathrm{A}$ & $11-17$ & $20-25$ & $7-9$ & - & - & $0.1-0.2$ & $1-2$ & $5-10$ & $1-2$ \\
\hline \multirow[t]{2}{*}{ Liming } & $\mathrm{C}$ & $53-97$ & $79-122$ & $28-45$ & - & $3.9-8.7$ & $0.4-0.5$ & $6-8$ & $5-15$ & $1-2$ \\
\hline & $\mathrm{A}$ & $14-26$ & $46-65$ & $16-24$ & - & $0.4-0.7$ & $0.1-0.2$ & $3-4$ & $1-2$ & $1-2$ \\
\hline \multirow{2}{*}{$\begin{array}{l}\text { Deliming, } \\
\text { Bating }\end{array}$} & $\mathrm{C}$ & $8-12$ & $13-20$ & $5-9$ & - & $0.1-0.3$ & $2.6-3.9$ & $3-5$ & $2-4$ & $10-26$ \\
\hline & $\mathrm{A}$ & $8-12$ & $13-20$ & $5-9$ & - & $0-0.1$ & $0.2-0.4$ & $0.6-1.5$ & $1-2$ & $1-2$ \\
\hline \multirow[t]{2}{*}{ Tanning } & C & $5-10$ & $7-11$ & $2-4$ & $2-5$ & - & $0.6-0.9$ & $0.6-0.9$ & $40-60$ & $30-55$ \\
\hline & $\mathrm{A}$ & $1-2$ & $7-11$ & $2-4$ & $0.05-0.1$ & - & $0.1-0.2$ & $0.1-0.2$ & $20-35$ & $10-22$ \\
\hline \multirow{2}{*}{$\begin{array}{l}\text { Post- } \\
\text { Tanning }\end{array}$} & $\mathrm{C}$ & $6-11$ & $24-40$ & $8-15$ & $1-2$ & $=$ & $0.3-0.5$ & $1-2$ & $5-10$ & $10-25$ \\
\hline & A & $1-2$ & $10-12$ & $3-5$ & $0.1-0.4$ & - & $0.1-0.2$ & $0.2-0.5$ & $3-6$ & $4-9$ \\
\hline \multirow[t]{2}{*}{ Finishing } & $\mathrm{C}$ & $0-2$ & $0-5$ & $0-2$ & - & - & - & - & - & - \\
\hline & $\mathrm{A}$ & $0-2$ & 0 & 0 & - & - & - & - & - & - \\
\hline \multirow[t]{2}{*}{ Total } & $\mathrm{C}$ & $83-149$ & $145-231$ & $50-86$ & $3-7$ & $4-9$ & $4-6$ & $12-18$ & $137-202$ & $52-110$ \\
\hline & $\mathrm{A}$ & $35-61$ & $96-133$ & $33-51$ & $0.15-0.5$ & $0.4-0.8$ & $0.6-1.2$ & $5-8$ & $30-55$ & $17-37$ \\
\hline
\end{tabular}

COD Chemical Oxyqen Demand, $\mathrm{BOD}_{5}$ Biological Oxygen Demand (in five days), SS Suspended Solids, TKN Total Kjeldahl Nitrogen

\begin{tabular}{|c|c|c|c|c|c|c|c|c|c|c|}
\hline \multicolumn{11}{|c|}{$\begin{array}{l}\text { Table 07(b): Typical values of Tannery waste water Treatment efficiency for } \\
\text { Conventional process }\end{array}$} \\
\hline \multirow{2}{*}{$\begin{array}{c}\text { Parameter } \\
\% \text { or } \mathrm{mg} / \\
\end{array}$} & \multicolumn{2}{|c|}{ COD } & \multicolumn{2}{|c|}{$\mathrm{BOD}_{5}$} & \multicolumn{2}{|c|}{ ss } & \multirow{2}{*}{$\begin{array}{c}\text { Chrome } \\
\mathrm{mg} / \mathrm{l} \\
\end{array}$} & \multirow{2}{*}{$\frac{\mathrm{s}^{2-}}{\mathrm{mg} / \mathrm{l}}$} & \multicolumn{2}{|c|}{ TKN } \\
\hline & $\%$ & $\mathrm{mgll}$ & $\%$ & $\mathrm{mg} / \mathrm{h}$ & $\%$ & $\mathrm{mg} / \mathrm{l}$ & & & $\%$ & $\mathrm{mg} / \mathrm{h}$ \\
\hline \multicolumn{11}{|l|}{ Pretreatment } \\
\hline $\begin{array}{l}\text { Grease removal } \\
\text { (dissolved air flotation) }\end{array}$ & $20-40$ & & & & & & & & & \\
\hline $\begin{array}{l}\text { Sulphide oxidation } \\
\text { (liming and rinsing } \\
\text { liquors) }\end{array}$ & 10 & & & & & & & 10 & & \\
\hline Chromium precipitation & & & & & & & $1-10$ & & & \\
\hline \multicolumn{11}{|l|}{ Primary treatment } \\
\hline Mixing + sedimentation & $25-35$ & & $25-35$ & & $50-70$ & & $20-30$ & & $25-35$ & \\
\hline $\begin{array}{l}\text { Mixing + chemical } \\
\text { treatment + } \\
\text { sedimentation }\end{array}$ & $50-65$ & & $50-65$ & & $80-90$ & & $2-5$ & $2-10$ & $40-50$ & \\
\hline $\begin{array}{l}\text { Mixing + chemical } \\
\text { treatment + flotation }\end{array}$ & $55-75$ & & $55-75$ & & $80-95$ & & $2-5$ & $2-5$ & $40-50$ & \\
\hline \multicolumn{11}{|l|}{ Biological treatment } \\
\hline $\begin{array}{l}\text { Primary or chemical + } \\
\text { extended aeration }\end{array}$ & $85-95$ & $200-400$ & $90-97$ & $20-60$ & $90-98$ & $20-50$ & $<1$ & $<1$ & 50 & 150 \\
\hline $\begin{array}{l}\text { Primary or chemical + } \\
\text { extended aeration with } \\
\text { nitrification and } \\
\text { denitrification }\end{array}$ & $85-95$ & $200-400$ & $90-97$ & $20-60$ & $90-98$ & $20-50$ & $<1$ & $<1$ & $80-90$ & $30-60$ \\
\hline
\end{tabular}


Fig.1(a) Leather industries and toxic chemicals released in nature

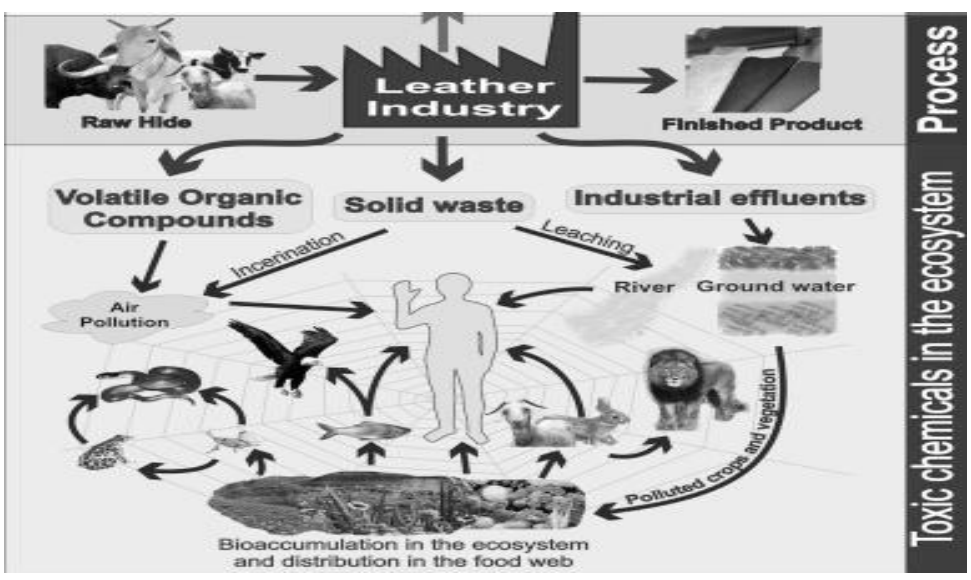

Fig.1(b) Map showing location of tanneries in India

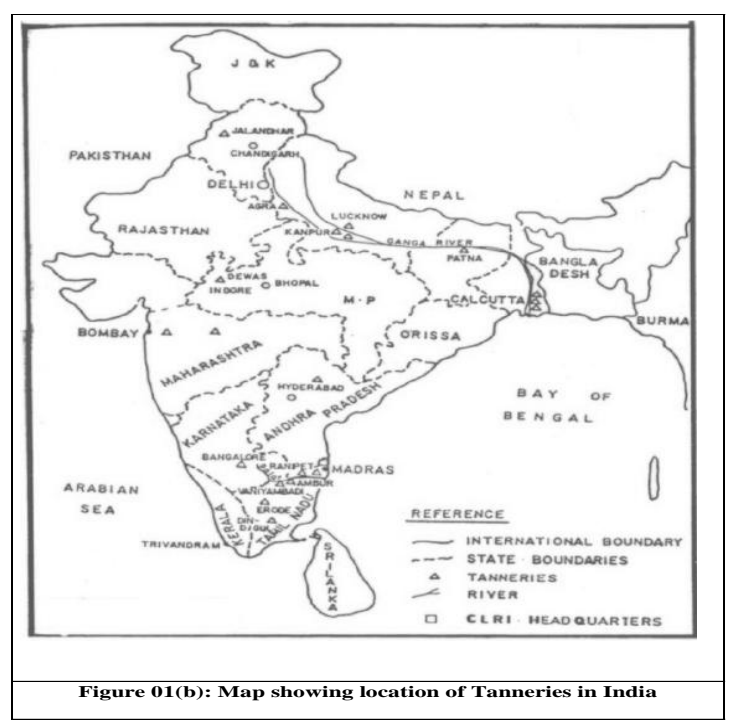

Fig.2 Sections and sub-sections of various processes

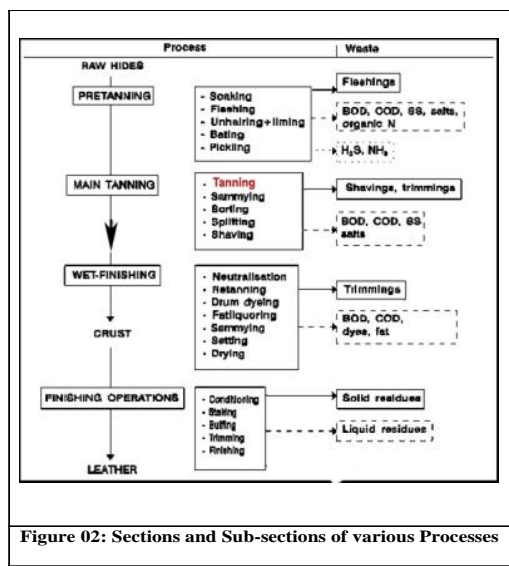


Fig.3 Desire to create this situation

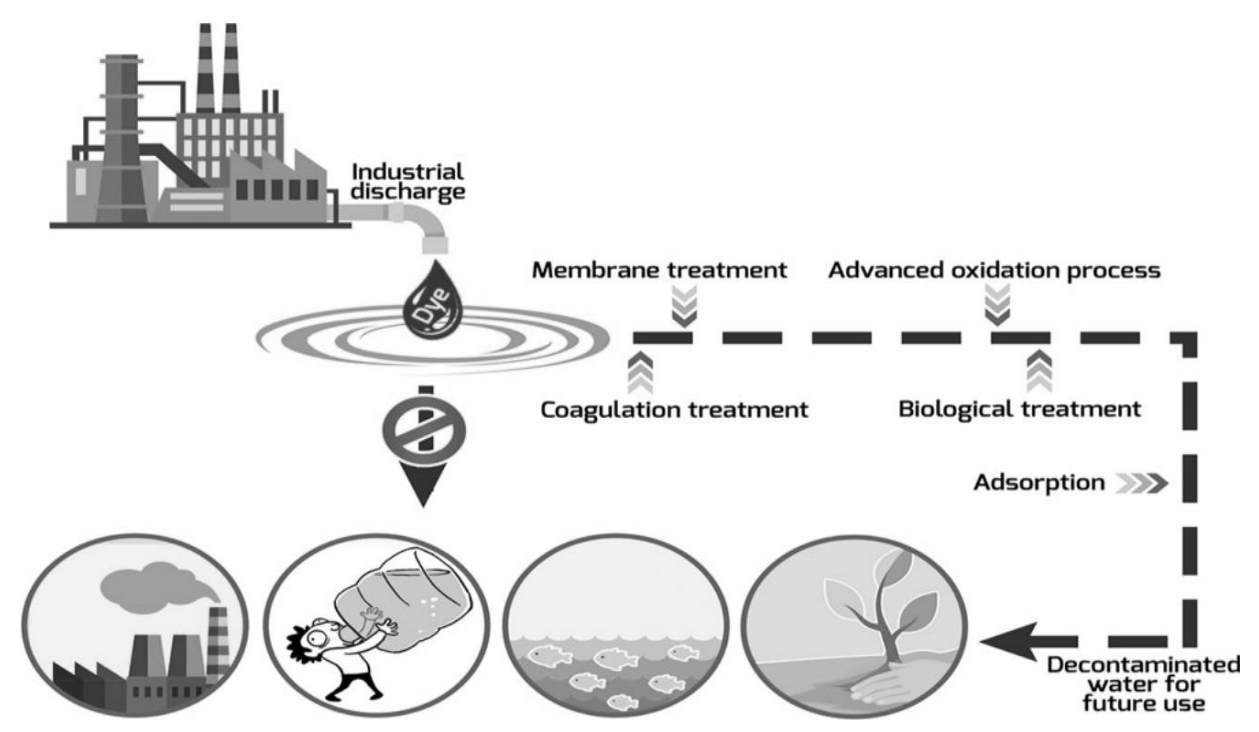

Sammying: Mechanical expulsion of water from the wet blue or wet white to a dampness substance of roughly half. Drying the shrouds builds the viability of the downstream parting and shaving measures.

\section{Color-house Process Stages (wet finishing and dry finishing)}

Splitting and shaving: These are mechanical techniques used to lessen the thickness of the stow away or skin to the thickness needed in the last calfskin. Parting subsequent to tanning is known as chrome parting.

Washing: Skins/hides are washed to remove leftover from splitting \& shaving in water.

Neutralization: Neutralization is the increasing of $\mathrm{pH}$ of wet blue/white to allow synthetics penetration in succeeding process stages.

Retanning: Introduction of various sorts of compound into the wet blue or wet white that confer explicit properties (such as flexibility, fullness and texture) on final leather.
Dyeing: Addition of powder/liquid colors in order to give the final leather the demanded or desired color.

Fat liquoring: Addition of emulsified oils used to soften the leather and make it flexible.

Fixation: It is the synthetic binding of all Retanning synthetics, colors and fat liquors to leather by decreasing the $\mathrm{pH}$ by the use of formic acid in the drum.

Final wash: The last wash is done to clean out any remaining unbound synthetic substances from the shading house measures.

\section{Drying, mechanical finishing and coating}

In the wake of drying, further completing of the calfskin can be performed to accomplish the ideal item.

Types of Colors Used In Leather Industries: Calfskin coloring for the most part includes the utilization of soul or liquor based colors where liquor rapidly gets retained into saturated livestock's hide. 
Calfskin coloring details are like enamels. They comprise of a color or shade, a casein or nitrocellulose sap, and a dissolvable.

The sorts of color stuff that are utilized by tanneries for the most part differs relying upon the item range required alongside the directs of the style world. Each tannery utilizes between 50-100 or more various kinds of colorstuffs. The calfskin business basically utilizes anionic color that can be separated in the accompanying families:

$\begin{array}{ll}\text { - } & \text { Acid colors } \\ \text { - } & \text { Dordant colors } \\ \text { - } & \text { Basic Colors } \\ \text { - } & \text { Pre-metaled their use is to a limit. } \\ & \text { Solubilized Sulphur colors }\end{array}$

Reactive colors although it's a part of the anionic group of colors but the use is limited upto a certain limit.

In the event that we see from the synthetic perspective the colors utilized are generally Azo colors, Anthraquinone colors and Triphenylmethane colors. Industrially, well known Black colors represent almost 60-70\% of all livestockshide coloring. Additionally, out of this a color assortment called Acid Black 210 rules with $80-90 \%$ use of the entirety of the dark colors utilized.

\section{Objective}

As we can see from the above process, their demands for water and with rapidly increasing industrialization which is directly linked to demand. I am trying to design a new process for textile and tannery wastewater treatment and we can see from the above processes that the common effluent discharge is basically composed of colors including heavy metal which are harmful for human as well as all living surrounding either directly or indirectly. Regarding my Bachelors Project work, have worked on household waste management considering Kanpur chapter. During all these years of work and research, I have become keenly aware of the urgency of environmental issues, especially for our country. Among all the issues, the wastewater problem might be the worst. Partly because of the lack of adequate public attention and appropriate government legislation and policy in the past decades, wastewater treatment in India becomes far behind developed countries so I want to work regarding textile(Varanasi) and tannery/leather industry (Unnao, Kanpur) as it can be found on Ganga belt affecting majority of the northern India region as Ganga belt(covering large area)and I will try my best providing a new economically feasible design which will help industry and the people (Table 1-5 and Fig. 1-3).

In conclusion the investigations demonstrated that textile wastewater can cause hemorrhages, skin ulceration, stress and dermatitis. Synthetic compounds present in water can obstruct sunlight and thus increment of the natural contamination in the water in this manner hindering photosynthesis and re-oxygenation.

In today's era the LI's are confronting some genuine difficulties presented by general society and governments primarily because of the natural contamination and there is a public objection against the business. The significant difficulties looked by LI's are:

Increased cost of leather creation per unit zone because of the rigid ecological guidelines.

Increasing request of crude material for example crude stows away, skins and semicompleted leather.

Lack of APO's and waste treatment advancements in agricultural nations. 
Hence I must conclude my assembled data and thanks to my Respective Guide Prof. Dr. Pradeep Srivastava, who helped me a lot and I hope his blessings will shower in future also. I am trying to design a new process which will be mutually benefitting all environmental elements which I'll try to bring in my upcoming publications

\section{References}

Arya D, Kohli P (2009) Environmental Impact of Textile Wet Processing, India. Colors and Chemicals.

Arya, D., and Kohli, P. (2009). Environmental impact of textile wet processing, India. ColorsandChemicals.http://www.fibre2fas hion.com/industryarticle/21/2047/environmental-impact-oftextile1.asp.

ATA (2007) Decline Trend in Global Nylon Production. Journal for Asia on Textile \& Apparel.

Bes-Pia A, Roca M, Alcover L, Clar A, Clar M, et al. (2002) Comparison between Nanofilteration and Ozonation of Biologically treated Textile Wastewater for its Reuse in the Industry. Desalination 157: 81-86.

Björnsdóttir, Anna Regína. Financial Feasibility Assessments.Building and Using Assessment Models for Financial Feasibility Analysis of Investment Projects.Diss. 2010.

BVSDE (2010) Section 5: Design of Common Effluent Treatment Plants for Nonhazardous Industrial Wastewater.

Chen X, Shen Z, Zhu X, Fan Y, Wang W (1996) Advanced Treatment of Textile Wastewater for Reuse Using Electrochemical Oxidation and Membrane Filtration. Chinese Academy of Science.

Cotton Inc (2013) Monthly Economic Letter. Cotton Market Fundamentals \& Price Outlook.

CPPC (Code of Practice on Pollution Control) (2000) Allowable Limits for Trade Effluent Discharged into A Public Sewer/Watercourse/Controlled
Watercourse.

Davis S, Schlag S, Funada C (2008) CHE Product Review Abstract. Chemical Industries.

Dizge N, Aydiner C, Demirbas E, Kobya M, Kara $\mathrm{S}$. Adsorption of reactive colors from aqueous solutions by fly ash: kinetic and equilibrium studies. J Hazard Mater 2008; 150:737-46.

DOE (Department of Environment) (2008) Guide for Assessment of Effluent Treatment Plants EMP/EIA Reports for Textile Industries. Ministry of Environment and Forest, Bangladesh.

El-Dein AM, Libra J, Wiesmann U. Cost analysis for the degradation of highly concentrated textile color wastewater with chemical oxidation $\mathrm{H} 2 \mathrm{O} 2 / \mathrm{UV}$ and biological treatment. J Chem Technol Biotechnol 2006; 81:1239-45.

Elkady, M. F., A. M. Ibrahim, and M. M. A. ElLatif, Assessment of the adsorption kinetics, equilibrium and thermodynamic for the potential removal of reactive red color using eggshell biocomposite beads, Desalination, vol. 278, no. 1, pp. 412423, 2011.

Environmental Commision of IULTCS: Typical Pollution Values Related to Conventional Tannery Processes, London, 1997

EPA (Environmental Protection Agency) (2003) Wastewater Technology Fact Sheet: Screening and Grit removal.

European Commission, Direcorate-General Joint Research Centre, Institute for Prospective Technological Studies (Seville) Technologies for Sustainable Development European Integrated Pollution Prevention and Control (IPPC) Bureau: Reference Document on Best Available Techniques for Tanning of Hides and Skins, 2001

FAO (2013) Food and Agriculture Organization of the United Nations FAOSTAT.

Ferrero F. Color removal by low cost adsorbents: hazelnut shells in comparison with wood sawdust. J Hazard Mater 2007; 142:14452.

Galán, J., A. Rodríguez, J. M. Gómez, S. J. Allen, and G. M. Walker, Reactive color adsorption onto a novel mesoporous carbon, Chem. Eng. J., vol. 219, pp. 62- 
68, 2013.

Georgiou, D., Aivazidis, A., Hatiras, J and K, Gimouhopouls. 2003. Treatment of Cotton Textile Wastewater Using Lime and Ferrous Sulfate. Water Research 37: 2248-2250.

Jaap Kok Environmentally sound leather tanning - A course on small-scale techniques and management, TOOL Foundation, Amsterdam, 1991

Jamal, T. and Ongsakul, W., 2012, March. Smart Grid in Bangladesh power distribution system: Progress \& prospects. In 2012 Students Conference on Engineering and Systems (pp. 1-5). IEEE.

Kant, R., Textile coloring industry an environmental hazard, Nat. Sci., vol. 04, no. 01, pp. 22-26, 2012.

Kara, S. T. Akar, T. Akar, and A. Ozcan, Dithiocarbamated Symphoricarpus albus as a potential biosorbent for a reactive color, Chem. Eng. J., vol. 211, pp. 442452, 2012.

Khatri, A., Peerzada, M.H., Mohsin, M. and White, M., 2015. A review on developments in coloring cotton fabrics with reactive colors for reducing effluent pollution. Journal of Cleaner Production, 87, pp.50-57.

Kirk-Othmer (2007) Encyclopedia of Chemical Technology. 3, 4th edn, John Wiley and Sons, Inc.

Kumar, G. N. P. and S. K. Bhat, Decolourization of azo color Red 3BN by bacteria, Int. Res. J. Biol. Sci., vol. 1, no. 5, pp. 46-52, 2012.

Kumar, R. and R. Ahmad, Biosorption of hazardous crystal violet color from aqueous solution onto treated ginger waste (TGW), Desalination, vol. 265, no. 1, pp. 112-118, 2011.

L.A.H.M. Verheijen D. Wiersema, L.W. Hulshoff Pol, J. De Wit Livestock and the Environment: Finding a Balance Management of waste from animal product processing, International Agriculture Centre, Wageningen, The Netherlands, 1996

Manu B (2003) Decolourization of indigo and azo color in semicontinous reactors with long hydraulic retention time. $\mathrm{PhD}$ thesies submitted to IIT Bombay, India.

Mazumder, D., Process evaluation and treatability study of wastewater in a textile coloring industry, Int. J. Energy Environ., vol. 2, no. 6, p. 1053, 2011.

Moussavi, G. and R. Khosravi, The removal of cationic colors from aqueous solutions by adsorption onto pistachio hull waste, Chem. Eng. Res. Des., vol. 89, no. 10, pp. 2182-2189, 2011.

Muthu, S. S. (2014). Assessing the environmental impact of textiles and the clothing supply chain. Elsevier.

Naik, D. J., H. H. Desai, and T. N. Desai, Characterization and treatment of untreated wastewater generated from colors and color intermediates manufacturing industries of sachin industrial area, Gujarat, India, J. Environ. Res. Dev., vol. 7, no. 4A, p. 1602, 2013.

Protrade/GTZ Ecology and Environment in the Leather Industry - Technical Handbook, Eschborn, 1995

Rahman MdM, Khan MdMR, Uddin MDT, Islam MdA. Textile effluent treatment plant sludge: characterization and utilization in building textile. Arab J Sci Eng 2017; 42:1435-42.

RIS (Relevant Indian Standards) (2003) General Standards for Discharge of Effluents.

Roohi M, Riaz M, Arif MS, Shahzad SM, Yasmeen T, Riaz MA, et al. Varied effects of untreated textile wastewater onto soil carbon mineralization and associated biochemical properties of a dryland agricultural soil. J Environ Manage 2016;183:530-40

Tunali Akar, S., A. Gorgulu, T. Akar, and S. Celik, Decolorization of Reactive Blue 49 contaminated solutions by Capsicum annuum seeds: Batch and continuous mode biosorption applications, Chem. Eng. J., vol. 168, no. 1, pp. 125-133, 2011.

Saharan, V. K., M. A. Rizwani, A. A. Malani, and A. B. Pandit, Effect of geometry of hydrodynamically cavitating device on degradation of orange-G, Ultrason. Sonochem. vol. 20, no. 1, pp. 345-353, 2013.

Sujataha V (2002), Leather Processing- Role of 
Indigenous Technology, Economic \& Political Weekly, Nov 23, 2002.

Sun D, Zhang X, Wu Y, Liu X. Adsorption of anionic colors from aqueous solution on fly ash. J Hazard Mater 2010; 181:33542.

Szpyrkowicz L, Juzzolino C, Kaul SN (2001) a comparative study on oxidation of disperse colors by electrochemical process, ozone, and hypochlorite and Fenton reagent. Water Res 35: 21292136.

TBW, Grohganz, Daniel; Eitner, Alexander Abwasserproblematik und -behandlung in Gerbereien, Frankfurt, Germany, 1995, http://www.epa.gov/EPA-

WATER/1996/July/Day-08/ (Leather Tanning and Finishing Effluent Limitations Guideline), http://www.ifc.org/enviro/FinancialMarke ts/FinancialMarkets/Studies/Tannery/tann ery.htm

Tewari, M \& Pillai, P (2005), Global Standards and the Dynamics of Environmental Compliance in India's Leather Industry, Oxford Development Studies (http://iegindia.org/workpap/wp255.pdf).

Tripathy T, De BR (2006) Flocculation: A New Way to Treat the Waste Water. Journal of Physical Science 10: 93-127.

Tsantaki E, Velegraki T, Katsaounis A, Mantzavinos D. Anodic oxidation of textile colorhouse effluents on borondoped diamond electrode. J Hazard Mater 2012; 207-208:91-6.

UNEP IE/PAC (1994), Tanneries and the
Environment. - A Technical Guide, Technical Report (2nd Print) Series No 4. Vijayaraghvan $\mathrm{K}$ and Murthy DVH (1997), Effect of toxic substances in anaerobic treatment of tannery wastewater, Bioprocess Biosys. Eng, 16: 151-155.

UNIDO - Regional Programme for Pollution Control in the Tanning Industry in SouthEast Asia The Scope for Decreasing Pollution Load in Leather Processing, 2000,

http://www.unido.org/userfiles/PuffK/L_s cope.pdf

UNIDO - Regional Programme for Pollution Control in the Tanning Industry in SouthEast Asia Chrome Management in the Tanyard, 2000, http://www.unido.org/userfiles/PuffK/L_c hrome_management.pdf

Wang, Z., M. Xue, K. Huang, and Z. Liu, Textile Coloring Wastewater Treatment, in Advances in Treating Textile Effluent, InTech, 2011.

Yadav, D. S. \& Aggarwal, Rajeev. (2007).Leather Sector: Global Export Performance and Issues in 21st Century. ICFAI Journal of Management Research, Vol. 6 Issue 10, Oct2007.

Zhong, Q. Q., Q.-Y. Yue, Q. Li, X. Xu, and B.-Y. GAO, Preparation, characterization of modified wheat residue and its utilization for the anionic color removal, Desalination, vol. 267, no. 2, pp. 193200, 2011.

\section{How to cite this article:}

Bhanu Pratap Singh and Pradeep Srivastava. 2020. Overview of Textile and Leather Industries Waste Treatment Processes. Int.J.Curr.Microbiol.App.Sci. 9(12): 1334-1353. doi: https://doi.org/10.20546/ijcmas.2020.912.164 